\title{
AUTOLOGOUS BONE PLUG SUPPLEMENTED WITH AUTOLOGOUS CHONDROCYTE \\ IMPLANTATION IN OSTEOCHONDRAL DEFECTS OF THE KNEE
}

Bhattacharjee A, McCarthy HS, Tins B, Roberts S, Kuiper JH, Harrison PE, Richardson JB.

To appear in: The American journal of sports medicine. 2016 May 1;44(5):1249-59.

\begin{abstract}
Background: Structural and functional outcome of bone graft with first or second generation autologous chondrocyte implantation $(\mathrm{ACl})$ in treating cartilage and subchondral bone defect has not been reported previously.
\end{abstract}

Aim: To evaluate the outcome of simultaneous transplantation of an autologous bone plug with first or second generation $\mathrm{ACl}$ for restoration of concomitant subchondral bone and full-thickness cartilage defect in the femoral condyle of the knee.

Study design: Case-series

Methods: Seventeen patients (mean age of $27 \pm 7$ years, range 17-40), twelve with osteochondritis dissecans (OD) (ICRS Grade 3 and 4) and five with an isolated osteochondral defect (OCD) (ICRS Grade 4) had their defect reconstructed with a combined implantation of a unicortical autologous bone graft with $\mathrm{ACl}$ (the Osplug technique). Functional outcome was assessed with Lysholm scores obtained pre-operatively and at one and five years postoperatively. The repair site was evaluated with the Oswestry Arthroscopy Score (OAS), 
MOCART MRI score and ICRS II histology score. Formation of subchondral lamina and lateral integration of the bone grafts were evaluated from MRI scans.

Results: The mean defect size was $4.5 \pm 2.6 \mathrm{SD} \mathrm{cm}^{2}$ (range 1-9) and mean depth was $11.3 \pm 5 \mathrm{SD}$ mm (range 5-18). The pre-operative Lysholm score improved from 45 (IQR 24, range 16-79) to 77 (IQR 28, range 41-100) at 1 year (p-value 0.001) and 70 (IQR 35, range 33-91) at 5 years ( $p$-value 0.009). The mean OAS of the repair site was 6.2 (range $0-9)$ at a mean of 1.3 years. The mean MOCART score was $61 \pm 22$ SD (range $20-85$ ) at $2.6 \pm 1.8$ SD years. Histology demonstrated generally good integration of the repair cartilage with the underlying bone. Poor lateral integration of the bone graft assessed on the MRI scan and a low OAS were significantly associated with a poor Lysholm score and failure.

Conclusion: The Osplug technique shows significant improvement of functional outcome for up to 5 years in patients with a high grade OD or OCD. This is the first report describing association of bone graft integration with functional outcome after such a procedure. It also demonstrates histological evidence of integration of the repair cartilage with the underlying bone graft.

\section{What is known on this subject?}

Successful clinical outcome of concurrent bone graft with $\mathrm{MACl}$ is reported in the past for $O D$ and OCD. Remodelling of the lamina and degree of cartilage fill is positively correlated with the clinical outcome.

\section{What this study adds?}

Successful outcome of Osplug technique of simultaneous tailored mono-cortical autologous bone plug with first or second generation $\mathrm{ACl}$, irrespective of the size of the defect for up to 
5 years. A poor arthroscopic score and poor integration of the mono-cortical bone graft assessed with MRI is associated with poor clinical outcome and later failure of the intervention. Establishing good integration between the implanted cells and bone core appears critical to the long term success of the procedure. 


\section{Introduction}

Treating full-thickness cartilage loss associated with an underlying subchondral bone defect in young patients can be challenging. The most commonly reported aetiology which represents such a situation is osteochondritis dissecans (OD), a condition that primarily affects the subchondral bone before progressing to the overlying cartilage ${ }^{4}$. High grade OD (ICRS OD Grade 3 and 4) can lead to full thickness cartilage loss extending to the subchondral bone, potentially beyond $10 \mathrm{~mm}$ in depth. Isolated osteochondral defects (OCDs) can also extend below the subchondral bone plate into the cancellous bone (ICRS Grade 4, severely abnormal cartilage) and are usually observed after trauma ${ }^{2}$. It has been suggested that such defects, with underlying 'cavitation' of the bone, are amenable to bone graft during cartilage repair surgery including Autologous Chondrocyte Implantation(ACI) ${ }^{2}$. Different operative techniques have been described including drilling ${ }^{3,9}$ or fixation ${ }^{10,13}$ and the excision of the fragment ${ }^{29}$ in $O D$. Restoration of the articular surface with osteochondral autograft (OAT) ${ }^{11}$ or microfracture (MF) ${ }^{6,7}$ are other techniques and both have resulted in significant clinical improvement, although results after OAT were better than after MF in patients with OD or isolated osteochondral defects. A 'sandwich' technique with bone graft and $\mathrm{ACl}$ has also been described in 7 patients with $\mathrm{OD}$, specifically

used to treat defects deeper than $10 \mathrm{~mm}$ by using a bi-layer periosteal patch, one being attached to the bone graft and the other anchored to the adjacent cartilage with chondrocytes injected between the layers although results from this technique were not reported separately ${ }^{19}$.

A subsequent modification of the 'sandwich' technique with matrix-induced $\mathrm{ACl}(\mathrm{MACl})$ and autologous cancellous bone graft, the bi-layer collagen membrane technique (BCMT) 
reported encouraging results in patients with $O D$ and $O C D^{1,27}$. The benefit of using $A C l$ as a restorative surgery for such cases lies in its ability to address defects larger than $2.5 \mathrm{~cm}^{2} 5$ and deeper than $8-10 \mathrm{~mm}$ by employing a concurrent autologous bone graft ${ }^{19,27}$. A further technique of autologous cancellous graft and single layer $\mathrm{MACl}$ has also been described to treat ICRS Grade 3 and Grade 4 OD ${ }^{18,24}$. Progressive remodelling of the subchondral lamina and filling of the cartilage defect following use of this particular technique was demonstrated with serial MRI scans from 26 patients. Remodelling and filling were observed to be positively correlated with the functional outcome ${ }^{18}$. However, none of the previous reports describes the structural outcome of the subchondral bone graft and its potential clinical implications. Additionally, a striking paucity of information exists with regards to the structural integration of the grafted bone and repair cartilage interface.

In the current study, we describe the 'Osplug' technique of using a single precise monocortical autologous bone cylinder graft with first and second generation $\mathrm{ACl}$ to simultaneously restore the subchondral bone and cartilage defect in patients with OD (ICRS Grade 3 and 4) and isolated OCD (ICRS Grade 4) of the knee joint. Additionally, we report the clinical, arthroscopic, MRI and histological outcome of patients treated with this technique.

\section{Methods}

The present study was approved by the Audit Committee of our hospital with regards to the clinical and imaging review. The histological analyses of the biopsies were approved by the local research ethics committee as part of the Retrospective Assessment of $\mathrm{ACl}$ (REACT) study (REC number: 09/H1203/90). All cases were operated by the senior author (JBR) from 2003-2008. All patients had pre-operative MRI scans to confirm the presence of cartilage 
and subchondral bone defects. Patients with a minimum defect depth of $5 \mathrm{~mm}$ were included in the study. Radiographs were undertaken to ascertain the absence of malalignment in the knee. Previous surgeries to treat the condition were recorded, excluding the first stage of $\mathrm{ACl}$. Failure was defined as a Lysholm score below the pre-operative value, requirement of further surgical interventions (except one year arthroscopy used to assess the repair site) or total knee replacement (TKR).

\section{Surgical Technique}

The surgical technique had two stages. The first stage comprised an arthroscopy and cartilage biopsy to harvest the chondrocytes. The second stage comprised insertion of a unicortical autologous bone graft in the subchondral bone defect and implantation of the autologous chondrocytes in the articular cartilage defect under a secured periosteum (first generation $\mathrm{ACl}$ ) or collagen patch (second generation $\mathrm{ACl}$ ). The second stage was performed approximately 3 weeks after the first stage (Figure 1 ).

\section{First stage}

During the first stage of the procedure, patients underwent a diagnostic arthroscopy to evaluate the site and extent of the defect. A cartilage biopsy was undertaken at this stage from the lesser weight-bearing area of the knee. The chondrocytes generated from the harvested cartilage were expanded in vitro for approximately 3 weeks in the Good Manufacturing Practice (GMP) standard 'Oscell' cell production facility in our center (Figure 1) ${ }^{8}$.

\section{$\underline{\text { Second stage }}$}


An arthrotomy was performed to access the cartilage and subchondral defect. The defect was debrided to healthy articular cartilage laterally and down to healthy bone. The size of the defect was measured with Vernier callipers and the exact location was recorded using the validated Oswestry Knee Map ${ }^{26}$. A cylindrical cortico-cancellous bone plug was then harvested from the non-articular part of the femoral condyle with a dowel drill. The monocortical bone plug was then tailored to the size of the subchondral defect. This was subsequently impacted into the defect with the cortex-side facing up to restore the subchondral plate and the underlying cancellous bone defect (Figure 2). The remaining chondral defect was then covered with a periosteal patch from the proximal tibia or a collagen membrane (Chondro-Gide ${ }^{\circledR}$; Geistlich Sons Ltd, Manchester, UK), which was sutured with 6-0 Vicryl (Ethicon, Livingston, UK) to the adjacent cartilage and sealed at the edges using fibrin glue (TISSEEL; Baxter, Newbury, UK). Periosteum was used until collagen membrane was available for use in patients in UK. Saline was injected under the patch to test for water tightness ('leak-test') and subsequently aspirated. Cultured autologous chondrocytes suspended in autologous serum were implanted beneath the patch through a 20 gauge Yale Spinal Needle (Becton Dickinson, Oxford, UK). This novel method of concurrent mono-cortical cylinder graft with first or second generation $\mathrm{ACl}$ was termed the Osplug technique.

\section{$\underline{\text { Rehabilitation }}$}

A standardised rehabilitation protocol was followed for all patients with initial immobilisation of the knee for 6 hours followed by continuous passive movement from full extension of the knee to 45 degrees of flexion for the first 48 hours after surgery. Patients were subsequently allowed to partially weight-bear with a hinged knee brace for 6-8 weeks. 


\section{$\underline{\text { Outcome assessment }}$}

Primary outcome- Functional outcome for this study was assessed using the patient reported modified Lysholm scale for the assessment of cartilage defects ${ }^{23}$ pre-operatively, one year and five years after the surgery. All three scores were collected prospectively by the Oswestry Outcome Centre.

Arthroscopic assessment- Patients had arthroscopic assessment of the repair site documented in the knee map using the validated Oswestry Arthroscopy Score (OAS; ${ }^{22}$ ) approximately one year after the second stage of the procedure. Five parameters were assessed: the level of the treated articular surface compared to the surrounding cartilage (0$2)$, integration with the surrounding cartilage (0-2), appearance of the surface (0-2), colour of the graft (0-2), and stiffness of the graft on probing (0-2). The total score ranges from 010, with higher values indicating a better quality of repair tissue.

Histological assessment- Biopsies of the repair tissue at the treated site were obtained during follow-up arthroscopic assessment of the knee. This was not routine and only performed if patients consented to the additional procedure. The Oswestry Knee Map, which recorded the site of the defect during the second stage, was used to ascertain the location of the graft. A core biopsy was taken with a Jamshidi needle close to the centre of the treated defect and included both the chondral and the underlying subchondral bone repair tissue. Biopsies were snap-frozen in liquid nitrogen-cooled hexane, embedded in OCT compound (Tissue-Tek, Zoeterwoude, Netherlands) and cryo-sectioned to produce $7 \mathrm{~mm}$ thick sections which were collected onto poly-L-lysine coated slides. These were then stained with either haematoxylin and eosin (H\&E) or toluidine blue for histological assessment of the general morphology of the repair tissue and glycosaminoglycan content, 
respectively, as per standard protocols ${ }^{20}$. The biopsy was assessed with bright light and polarised light microscopy for the morphology and collagen organization. Sections were scored semi-quantitatively using the International Cartilage Repair Score II (ICRS II; ${ }^{12}$ ), assessing the quality of the repair tissue. This has 14 parameters, each with a range of 0-10 with higher values indicating better quality. One parameter, the 'overall score', assesses the full biopsy.

MRI Scans - MRI scans were also used to assess the quality of repair following the surgery. All MRIs were scored by a single musculoskeletal radiologist, with expertise in cartilage imaging, in conjunction with an orthopaedic surgeon inclined towards cartilage repair surgery.

The MRI acquisition was composed of coronal and sagittal spin echo T1 and gradient echo T2 weighted sequences; axial dual echo (proton density and T2 weighting) and 3D fat suppressed FLASH and 3D DESS sequences were also acquired. A 1.5 Tesla unit with $25 \mathrm{mT} / \mathrm{m}$ gradient strength (Siemens Vision, Erlangen, Germany) and a standard Siemens viewing station and software (VB33A) were used. The parameters for the five sequences were:

1) SE T1 : Flip angle $90^{\circ}$, TR 722, TE 20, FOV 200, matrix 336x512.

2) GRE T2: Flip angle $30^{\circ}$, TR 608, TE 18 , FOV 200, matrix $224 \times 512$ matrix.

3) Axial dual echo images: Turbo spin echo flip angle $180^{\circ}$, echo train length 5 , spectral fat saturation, TR 3500, TE 16/98, FOV 175×200, matrix 210×256.4) 3D FLASH: Spectral fat saturation. Flip angle $30^{\circ}$, TR $50 \mathrm{~ms}$, TE $11 \mathrm{~ms}$, TA 9:38 min, FOV 180x180 mm, matrix $192 \times 256$, slab=90mm displayed as 60 continuous sagittal images of $1.5 \mathrm{~mm}$ thickness. 
5) 3D DESS: Spectral fat saturation and magnetization transfer. Flip angle $40^{\circ}$, TR $58.6 \mathrm{~ms}$, TE $9 \mathrm{~ms}$, TA $12: 01 \mathrm{~min}$, FOV $180 \times 180 \mathrm{~mm}$, matrix $192 \times 256$, slab=96mm displayed as 64 continuous sagittal images of $1.5 \mathrm{~mm}$ thickness.

The cartilage repair site was semi-quantitatively assessed with magnetic resonance observation of cartilage repair tissue (MOCART) parameters ${ }^{14,15,28}$. In addition, special attention was paid to determine if a subchondral lamina had reformed post-treatment (referred to as a 'neo-lamina') and also to the underlying autologous bone graft. The presence 'neo-lamina' which is indicated to be a continuous process of remodelling was assessed along the whole dimension of the bony defect and placed into one of four categories as described by Ochs et al, i.e Grade-1 (0-25\% of defect diameter), Grade-2 (26$50 \%$ defect diameter), Grade-3 (51-75\% defect) and Grade-4 (>76\% defect diameter) ${ }^{18}$.

Lateral integration of the cylindrical bone graft was assessed in both the coronal and sagittal planes at the graft and the host bone junction on the MRI scans. The presence of continuous trabeculae along this whole interface indicated $100 \%$ integration whilst the persistence of trabecular discontinuity indicated lack of integration. The lateral integration was semiquantitatively classified into four categories: Grade-1 (<25\%), Grade-2 (26-50\%), Grade-3 (51-75\%) and Grade-4 (76-100\%). The morphology of the central subchondral grafted bone was assessed for the presence of any cysts and for trabecular architecture within the graft and was graded from completely remodelled graft to disorganized bone graft or bone graft with formation of a cyst. Scans performed at least 12 months after the second stage of the surgery were evaluated to appraise the longer-term quality of the repair, presence of the neo-lamina and the integration of the mono-cortical bone cylinder graft.

\section{$\underline{\text { Statistics }}$}


A Shapiro-Wilk test was used to ascertain the normality of the data. The paired Wilcoxon Signed Rank test was used to demonstrate the difference between Lysholm scores at different time points. Rank-biserial and bivariate rank (Spearman) correlation analysis was used to investigate the relation between the Lysholm score and various categorical or continuous predictors and outcomes. IBM SPSS Statistics vs 22 (IBM UK Ltd, Portsmouth, UK) was used for the analysis of the data.

\section{$\underline{\text { Results }}$}

\section{Patient characteristics}

A total of 12 cases of OD (ICRS grade 3 and 4 ) and 5 cases of isolated OCD (ICRS grade 4) were included in this study. Their mean age at the time of surgery was 27 years \pm 7 SD (range 17-40). Fifteen patients had the defect on the medial femoral condyle and 2 on the lateral femoral condyle. Ten patients had a lesion in the right knee and 7 in the left knee. The mean defect size was $4.5 \mathrm{~cm}^{2} \pm 2.6 \mathrm{SD}$ (range 1-9). The mean defect depth was $11.3 \mathrm{~mm} \pm 5 \mathrm{SD}$ (range 5-18). Twelve patients had a collagen patch and 5 patients had a periosteal patch from the proximal tibia to cover the defect. Each patient received at least one previous surgery with a mean of 1.6 operations (range 1-4) to treat the defect; not including the $1^{\text {st }}$ stage of the $\mathrm{ACl}$ (Table 1). There was no association between the number of previous surgeries with 1 year Lysholm scores ( $p=0.47$, Spearman's rho -0.214$)$ and 5 years Lysholm scores $(p=0.96$, Spearman's rho -0.16$)$. One patient was lost to follow-up at 1 year and a further 2 patients were lost to follow-up at 5 years.

\begin{tabular}{|l|l|}
\hline $\begin{array}{l}\text { Patient } \\
\text { number }\end{array}$ & \multicolumn{1}{c|}{ Previous surgeries } \\
\hline 1 & Arthroscopy + removal of loose body + drilling \\
\hline
\end{tabular}




\begin{tabular}{|l|l|}
2 & $\begin{array}{l}\text { Arthroscopy }+ \text { removal of loose body; Arthroscopy + debridement +drilling; } \\
\text { Arthroscopy +microfracture }\end{array}$ \\
\hline 3 & Arthroscopy + Smiles's pin fixation; Arthroscopy +debridement +drilling \\
\hline 4 & Arthroscopy+ removal of loose bodies +debridement + drilling \\
\hline 5 & Arthroscopy+ removal of loose bodies +debridement \\
\hline 6 & Arthroscopy+ removal of loose bodies + debridement \\
\hline 7 & Arthroscopy+ removal of loose bodies + debridement \\
\hline 8 & Arthroscopy+ removal of loose bodies +microfracture \\
\hline 9 & Arthroscopy+ removal of loose bodies; Arthroscopy +drilling \\
\hline 10 & Arthroscopy+ removal of loose bodies +debridement \\
\hline 11 & Arthroscopy+ removal of loose bodies + debridement \\
\hline 12 & Arthroscopy+ removal of loose bodies, 3x Arthroscopy + debridement \\
\hline 13 & Arthroscopy+ removal of loose bodies +debridement \\
\hline 14 & Arthroscopy+ removal of loose bodies+ debridement; Arthroscopy + debridement \\
\hline 15 & Arthroscopy+ removal of loose bodies +microfracture \\
\hline 16 & Arthroscopy+ pin fixation; Arthroscopy +removal of loose bodies+ debridement \\
\hline 17 & Arthroscopy+ removal of loose bodies +microfracture; Arthroscopy + debridement \\
\hline
\end{tabular}

Table 1-Details of previous surgeries in patients treated with 'Osplug' technique

\section{Clinical outcome}

A Shapiro-Wilk test confirmed that the scores did not follow a normal distribution $(p=0.01)$. The median pre-operative Lysholm score was 45 (IQR 24, range 16-79). The median Lysholm score increased to 77 (IQR 28, range 41-100) at 1 year and was 70 (IQR 35, range 33-91) 5 years after the surgery. A Wilcoxon Signed Rank test showed statistically significant improvement of Lysholm scores at 1 year ( $p$-value 0.001 ) and 5 years ( $p$-value 0.009 ) in comparison to pre-operative scores. The difference in Lysholm scores at 1 and 5 years was not statistically significant $(p=0.50)$. 
No association was found between the type of patch used (periosteum/collagen) and Lysholm score at 1 year $(p$-value $=0.86$, point-biserial correlation-0.05) and 5 years ( $p$-value $=0.95$, point-biserial correlation-0.02). The clinical outcome was not related to the size (at one year, $p=0.8$ and five years, $p=0.3$ ) or depth (at one year, $p=0.7$ and five years, $p=0.2$ ) of the defect. Only one patient required a TKR during the follow up period at 5 years after the Osplug procedure with a Lysholm score of 33 prior to the joint replacement. The patient's score had increased from 16 before the Osplug procedure to 41 one year after it. Two patients required further surgical intervention, one at 2 years and one at 4 years because of persistent symptoms. Both had a Lysholm score of 45 prior to subsequent surgery, but in both cases this was higher than their score before the Osplug procedure.

\section{Arthroscopic assessment}

Eleven patients had arthroscopic assessment of the repair site at a mean of 1.3 years (range 0.7-2) post-operatively. The mean OAS was 6.2 (range 0-9). A statistically significant correlation was noted between OAS and Lysholm score at both 1 year $(p=0.008$, Spearman's rho 0.78 ) and 5 years ( $p$-value=0.046, Spearman's rho 0.64). Furthermore, a significant association between the OAS and failure of the Osplug technique was observed ( $p$-value = 0.001 , point-biserial correlation-0.865).

\section{$\underline{\text { Histological assessment }}$}

The mean value for the ICRS II 'overall score' for the repair tissue biopsies analysed was 5.2 \pm 1.6 SD (range 2.3-7.4; Table 1). Of the 10 biopsies obtained (from 8 patients), 9 were found to be fibrocartilage and one was a mixture of fibrocartilage and hyaline cartilage. Matrix metachromasia was very variable between different biopsies, with scores 
ranging from 2.7 to 8.9 , being nearly normal (with a maximum of 10 ) for 2 biopsies. The surface architecture was generally good to excellent. Integration of the repair cartilage to the underlying subchondral bone was also good, with the tidemark being visible in more than half of the biopsies (Figure 3). Cell morphology was variable throughout the biopsies, with some being fibroblastic in shape, whilst others were more rounded and of chondrocytic morphology; clustering of cells was rare. Three biopsies contained evidence of ectopic calcification. One of these was a second biopsy from patient 1 taken 13 months after the first biopsy, when no evidence of calcification was observed. One biopsy (from patient 9) showed quite extensive calcification. There was no evidence of either vascularisation or inflammation in any of the biopsies examined. 


\begin{tabular}{|c|c|c|c|c|c|c|c|c|c|c|c|c|c|c|c|}
\hline $\begin{array}{l}\text { Pt. } \\
\text { No. }\end{array}$ & $\begin{array}{c}\text { Months } \\
\text { post } \\
\text { ACl }\end{array}$ & $\begin{array}{c}\text { Tissue } \\
\text { Morphology }\end{array}$ & Staining & $\begin{array}{c}\text { Cell } \\
\text { Morphology }\end{array}$ & Clusters & Surface & Integration & Tidemark & SCB & Inflammation & Calcification & Vasc. & $\begin{array}{l}\text { Superficial } \\
\text { zone }\end{array}$ & $\begin{array}{l}\text { Mid/deep } \\
\text { zone }\end{array}$ & Overall \\
\hline 1 & 11 & 5.45 & 2.7 & 0.45 & 10 & 6.75 & 7.85 & 7.8 & 6.35 & 10 & 10 & 10 & 3.9 & 3.7 & 3.8 \\
\hline 1 & 24 & 5.35 & 3.55 & 0.7 & 10 & 7.75 & 9.5 & 0.05 & 9.9 & 10 & 8.7 & 10 & 4.3 & 4.75 & 4.35 \\
\hline 2 & 24 & 1.9 & 4.8 & 8.9 & 6.7 & 9.9 & 9.9 & 8.9 & 9 & 10 & 10 & 10 & 7.7 & 6.1 & 7.4 \\
\hline 3 & 13 & 3.9 & 5.8 & 7.8 & 10 & 8.4 & 9.8 & 8.2 & 4.5 & 10 & 10 & 10 & 6.4 & 5.4 & 5.5 \\
\hline 3 & 37 & 6.5 & 5.7 & 9.5 & 10 & 8.4 & 10 & 8.5 & 8 & 10 & 10 & 10 & 7.6 & 7.6 & 7.2 \\
\hline 4 & 12 & 5.55 & 8.9 & 5.5 & 9.95 & 9.55 & 9.95 & 1.1 & 8 & 10 & 10 & 10 & 7.2 & 6.65 & 6.75 \\
\hline 7 & 13 & 5.4 & 2.25 & 2.55 & 9.95 & 8.6 & $n / a$ & $n / a$ & 2.95 & 10 & 10 & 10 & 5.8 & 3.65 & 4.7 \\
\hline 9 & 22 & 4.1 & 2.7 & 5.1 & 10 & $n / a$ & $\mathrm{n} / \mathrm{a}$ & $n / a$ & $\mathrm{n} / \mathrm{a}$ & 10 & 1.4 & 10 & 2.7 & $\mathrm{n} / \mathrm{a}$ & 2.3 \\
\hline 12 & 18 & 5.15 & 6.55 & 9.1 & 10 & 9.45 & 9.2 & 0.55 & 2.2 & 10 & 2.75 & 10 & 5.75 & 4.15 & 5.2 \\
\hline 14 & 16 & 4.8 & 8.85 & 1.4 & 10 & $n / a$ & $\mathrm{n} / \mathrm{a}$ & $\mathrm{n} / \mathrm{a}$ & $\mathrm{n} / \mathrm{a}$ & 10 & 10 & 10 & $\mathrm{n} / \mathrm{a}$ & 4.95 & 4.65 \\
\hline
\end{tabular}

Table 2-Individual scores for the 14 parameters assessed with the ICRS II Histology Score ${ }^{12}$ for each biopsy

(SCB-subchondral bone, Vasc-vascularisation) 
One patient (Patient 3) with sequential biopsies taken at 13 and 37 months after the Osplug procedure demonstrated an interesting histological feature. Under polarised light, the 13 month biopsy showed collagen fibres running predominantly parallel between the cartilage and subchondral bone along the cartilage/bone graft interface; at 37 months, the orientation of the fibres in the bone had changed from being parallel to much more oblique, integrating the cartilage into the bone (Figure 4). In addition, the latest biopsy demonstrated an improvement in the individual ICRS II parameters for tissue morphology, cell morphology, subchondral bone, as well as the overall score, compared to the earlier biopsy.

\section{$\underline{\mathrm{MRI} \text { assessment }}$}

MRI scans were available from eleven patients, at a mean of 2.6 years \pm 1.8 SD (range $1-6$ ) after surgery. The overall MOCART score was 61 \pm 22 SD (range 20-85) (Table 2). Degree of defect fill with the repair tissue was noted to be complete in 4 patients. Two patients had exposed subchondral bone. In one patient (patient 2) the repair cartilage was hypertrophic for more than $50 \%$ of the defect diameter and showed incomplete fill (to a level of $>50 \%$ of the thickness of the adjacent cartilage) in the rest of the defect. Complete integration of the repair cartilage with adjacent healthy cartilage, represented by isointense signal intensity of the repair tissue compared to the adjacent cartilage, was noted in 8 patients (73\%). The neo-lamina was observed to be intact in only 3 patients; however it was seen to be partially formed in the rest indicating a continuous process of remodelling in the subchonral lamina. The subchondral bone was not intact in 10 patients, with cysts in 5 patients and disorganised bone graft with inhomogeneous signals in comparison to the adjacent bone in another 5 patients. 
Marginal integration of the 'Osplug' was classified as Grade 4 (76-100\%) in the orthogonal plane of the bone graft in 8 out of 11 patients (73\%; Figure 5). Interestingly, the three patients which failed had poor integration of the bone graft suggesting this to be a significant predictor to failure of the Osplug technique (Spearman's rho $0.8, p=0.003$ ). Lateral integration seen in MRI scan had significant positive correlation with a good clinical outcome at 1 year (p-value=0.007, Spearman's rho 0.75 ) although it failed to reach statistical significance at 5 years ( $p$-value=0.08, Spearman's rho 0.55 ). The grade of neolamina evident in MRI scans had significant positive correlation to time of the scan since surgery ( $p$-value $=0.001$, Spearman's rho 0.86 ), although no significant correlation was found with lateral integration of the bone graft $(p=0.15)$, MOCART scores $(p=0.8)$, one year Lysholm scores $(p=0.43)$ and five years Lysholm scores $(p=0.5)$ (Table 3$)$. 


\begin{tabular}{|c|c|c|c|c|c|c|c|c|c|c|c|c|c|}
\hline $\begin{array}{l}\text { Pt. } \\
\text { No. }\end{array}$ & $\begin{array}{c}\text { Time } \\
\text { of MRI } \\
\text { (years) } \\
\text { post- } \\
\text { ACI }\end{array}$ & $\begin{array}{c}\text { Degree of } \\
\text { repair + } \\
\text { filling of } \\
\text { defect }\end{array}$ & $\begin{array}{l}\text { Integration of } \\
\text { border of repair } \\
\& \text { native } \\
\text { cartilage? }\end{array}$ & $\begin{array}{l}\text { Surface of } \\
\text { the repair } \\
\text { cartilage }\end{array}$ & $\begin{array}{l}\text { Structure } \\
\text { of the } \\
\text { repair }\end{array}$ & $\begin{array}{c}\text { Signal intensity of } \\
\text { repair cartilage? } \\
\text { (DT2FSE/3D-GE- } \\
\text { FS) }\end{array}$ & $\begin{array}{l}\text { Subchondral } \\
\text { lamina }\end{array}$ & $\begin{array}{c}\text { Subchondral } \\
\text { bone }\end{array}$ & Adhesion & Effusion & $\begin{array}{l}\text { Total } \\
\text { MOCART } \\
\text { Score }\end{array}$ & 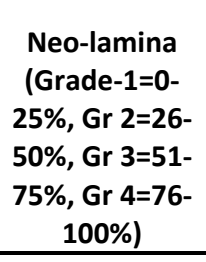 & $\begin{array}{c}\text { 'Osplug' lateral } \\
\text { integration ( Gr 1=0- } \\
\text { 25\%, Gr2=26-50\%, Gr } \\
3=51-75 \%, G r 4=76- \\
100 \% \text { ) }\end{array}$ \\
\hline 2 & 2 & 10 & 15 & 5 & 0 & 30 & 5 & 0 & 5 & 0 & 75 & 4.00 & 4.00 \\
\hline 3 & 6 & 10 & 15 & 5 & 5 & 30 & 5 & 5 & 5 & 5 & 85 & 4.00 & 4.00 \\
\hline 5 & 3 & 5 & 15 & 0 & 5 & 30 & 0 & 0 & 5 & 0 & 60 & 3.00 & 4.00 \\
\hline 9 & 1 & 20 & 10 & 5 & 5 & 30 & 0 & 0 & 5 & 0 & 75 & 1.00 & 3.00 \\
\hline 10 & 4 & 0 & 0 & 0 & 0 & 15 & 5 & 0 & 5 & 0 & 25 & 4.00 & 4.00 \\
\hline 11 & 1 & 20 & 15 & 5 & 5 & 30 & 0 & 0 & 5 & 0 & 80 & 1.00 & 4.00 \\
\hline 12 & 3 & 20 & 15 & 5 & 0 & 15 & 0 & 0 & 5 & 0 & 60 & 3.00 & 3.00 \\
\hline 14 & 2 & 20 & 15 & 5 & 0 & 30 & 0 & 0 & 5 & 0 & 75 & 3.00 & 4.00 \\
\hline 15 & 3 & 5 & 0 & 0 & 0 & 30 & 0 & 0 & 5 & 0 & 40 & 3.00 & 4.00 \\
\hline 16 & 1 & 15 & 15 & 5 & 0 & 30 & 0 & 0 & 5 & 0 & 70 & 1.00 & 4.00 \\
\hline 17 & 1 & 0 & 0 & 0 & 0 & 15 & 0 & 0 & 5 & 0 & 20 & 1.00 & 2.00 \\
\hline
\end{tabular}

Table $3 \mathrm{MRI}$ characteristics of the cartilage in the repair site according to the MOCART scale. Two other bone properties were also assessed:

the remodelling of the neo-lamina and the lateral integration of the mono-cortical cylinder graft

Scores ascertained to MOCART parameters are represented below ${ }^{28}$ -

a. Degree of defect fill and repair-Complete-20, Hypertrophy-15, Incomplete ( $>50 \%$ of adjacent cartilage)- 10 , Incomplete $(<50 \%$ of adjacent cartilage)-5, Subchondral bone exposed- 0 .

Integration of the border-Complete-15, Incomplete(split like border visible)-10, Defect visible $<50 \%$ of length-5, Defect visible $>50 \%$ of length-0

Surface of the repair tissue-Surface intact- 10 , Surface damaged $<50 \%$ of depth-5, Surface damaged $>50 \%$ of depth-0

Structure of the repair-Homogenous-5, Inhomogenous-0

Signal intensity of the repair tissue-Normal(identical to the adjacent cartilage)-15, Nearly normal-10, Abnormal-0

Subchondral lamina-Intact-5, Not intact-0

Subchondral bone-Intact-5, Not intact-0

. Adhesion-No-5, Yes-0

i. Effusion-No-5, Yes-0 
Table 4 Correlation matrix between variables

\begin{tabular}{|c|c|c|c|}
\hline \multicolumn{2}{|r|}{ Variables } & p- & Correlation coefficient \\
\hline \multirow{3}{*}{$\begin{array}{c}1 \text { year Lysholm } \\
\text { score }\end{array}$} & Lateral integration of bone graft & $0.007^{*}$ & 0.75 \\
\hline & OAS & $0.008 *$ & 0.78 \\
\hline & Neo-lamina & 0.43 & 0.27 \\
\hline \multirow{3}{*}{$\begin{array}{c}5 \text { year Lysholm } \\
\text { score }\end{array}$} & Lateral integration of bone graft & 0.08 & 0.55 \\
\hline & OAS & $0.046^{*}$ & 0.64 \\
\hline & Neo-lamina & 0.54 & 0.23 \\
\hline \multirow{3}{*}{ Failure } & Lateral integration of bone graft & $0.003^{*}$ & 0.8 \\
\hline & OAS & $0.001 *$ & 0.86 \\
\hline & Neo-lamina & 0.54 & 0.20 \\
\hline \multirow{2}{*}{$\begin{array}{l}\text { Time of MRI } \\
\text { from surgery }\end{array}$} & Neo-lamina & $0.004 *$ & 0.8 \\
\hline & Lateral integration & 0.27 & 0.36 \\
\hline
\end{tabular}

( $p$-value $<0.05$ (2-tailed) considered significant (marked with *), point-biserial and Spearman's correlation analysis was used to investigate the relation between the Lysholm score and various categorical or continuous predictors and outcome)

\section{Discussion}

This current work demonstrates that significant clinical and functional improvement can result for up to 5 years from the novel Osplug technique if patients have more severe OCD (ICRS 4) or OD (ICRS 3 and 4). The mean age of patients included in this study is 27 years with a mean defect size of $4.5 \mathrm{~cm}^{2}$ (range 1-9) and a mean depth of $11.3 \mathrm{~mm}$ (range 5-18), comparable to previous reports of treatment with simultaneous $\mathrm{ACl}$ and bone graft (Table 4). Moreover, all patients in our study had at least one previous surgical procedure (mean1.6, range 1-4) which is comparable to an earlier study ${ }^{27}$, although it has been described as primary procedure in a proportion of their patients in two further series describing $\mathrm{MACl}$ with bone graft ${ }^{18,24}$. Interestingly, these two studies of $\mathrm{MACl}$ and bone graft described a significant clinical and functional improvement at 12 months, which was maintained subsequently with no further significant rise or fall for a total follow-up of 36-39 months ${ }^{18,}$ 19, 24 . Our study noted a similar finding of a significant rise in Lysholm score at 1 year which 
was retained for at least 5 years of follow-up, with no further significant change in functional outcome in a patient group in which this technique was used as a salvage technique after at least one failed procedure.

The validated arthroscopy score ${ }^{22}$ for the repair site at 1.3 years was seen to have a significant positive correlation with the one and five year clinical outcome. This is the first report demonstrating an association of the functional outcome with the macroscopic quality of the repair site after simultaneous $\mathrm{ACl}$ and bone graft technique, where a poor arthroscopy score, indicative of sub-optimal graft, was linked with a higher rate of treatment failure. A further unique finding was the low grade of bone plug integration seen in MRI scans had significant correlation to poor clinical outcome at one year and failure of the procedure requiring re-intervention or TKR. These findings indicate the contribution of the richly innervated subchondral bone as a potential source of pain and functional limitation, especially if it occurs in association with loss of overlying cartilage ${ }^{25}$. 


\begin{tabular}{|c|c|c|c|c|c|c|c|}
\hline $\begin{array}{l}\text { Author \& } \\
\text { Year }\end{array}$ & $\begin{array}{c}\text { Patient } \\
\text { characteristics }\end{array}$ & Intervention & Bone graft & Clinical outcome & MRI feature & Histology & Arthroscopy \\
\hline $\begin{array}{l}\text { Peterson et } \\
\text { al,. } 2003\end{array}$ & $\begin{array}{c}58 \text { patients (OD) } \\
\text { mean age } 26.4 \text { years, } \\
\text { mean defect size } 5.7 \\
\text { sq.cm, mean depth } \\
7.8 \mathrm{~mm} \text { (only } 7 \\
\text { patients deeper than } \\
1 \mathrm{~cm} \text { treated with } \\
\text { bone graft) }\end{array}$ & $\begin{array}{l}\text { sandwich technique } \\
\text { with bi-layer } \\
\text { periosteum patch(1 } 1^{\text {st }} \\
\text { generation } \mathrm{ACl}) \text { with } \\
\text { bone graft(only in7 } \\
\text { patients) }\end{array}$ & $\begin{array}{l}\text { Loose cancellous } \\
\text { bone from iliac crest } \\
\text { or proximal tibia }\end{array}$ & $\begin{array}{l}\text { FU for mean } 5.6 \text { years. } \\
\text { Modified Cincinnati score, } \\
\text { Brittberg- Peterson score VAS, } \\
\text { Tegner Wallgren score and } \\
\text { Lysholm score significantly } \\
\text { improved at } 2 \text { years but no sig } \\
\text { difference from } 2 \text { year up to } 10 \\
\text { year. No specific results of } \\
\text { 'sandwich' technique }\end{array}$ & $\begin{array}{l}\text { 13/15 patients with } \\
\text { appearance of } \\
\text { normal looking } \\
\text { cartilage at } 3.5 \text { years, } \\
\text { deeper defects had } \\
\text { cyst. Suggestion of } \\
\text { bone remodelling } \\
\text { and filling but no } \\
\text { specific results for } \\
\text { 'sandwich' technique }\end{array}$ & No histology & $\begin{array}{l}22 \text { patients, } \\
\text { arthroscopic score } \\
\text { of graft integrity } \\
\text { mean } 11.2 / 12 \text { for } \\
\text { all patients(no } \\
\text { reports of patients } \\
\text { requiring bone } \\
\text { graft) }\end{array}$ \\
\hline $\begin{array}{l}\text { Bartlett et } \\
\text { al,. } 2005\end{array}$ & $\begin{array}{c}8 \text { patients }(5 \mathrm{OD}) \text {, } \\
\text { mean age } 26.4 \text { years, } \\
\text { mean defect size } 5.2 \\
\mathrm{sq} \mathrm{cm}\end{array}$ & $\begin{array}{l}\mathrm{MACl}+\text { cancellous graft } \\
\text { (bilayer collagen } \\
\text { membrane technique, } \\
\text { BCMT- } 3^{\text {rd }} \text { generation } \\
\text { ACl) }\end{array}$ & $\begin{array}{l}\text { Loose cancellous } \\
\text { bone graft from } \\
\text { distal femur }\end{array}$ & $\begin{array}{l}\text { FU for } 1 \text { year, Improvement in } \\
\text { modified Cincinnati knee score, } \\
\text { Visual analogue, Stanmore } \\
\text { functional score(p-value-NA) }\end{array}$ & Not done & $\begin{array}{l}1 \text { fibrocartilage } \\
\text { and } 1 \text { mixed } \\
\text { fibro/hyaline } \\
\text { with good } \\
\text { integration }\end{array}$ & $\begin{array}{l}2 \text { patients ICRS } \\
\text { grade nearly } \\
\text { normal and } 2 \\
\text { patients abnormal }\end{array}$ \\
\hline $\begin{array}{l}\text { Maus et al,. } \\
2008 \text { (article } \\
\text { in German) }\end{array}$ & $\begin{array}{l}13 \text { patients with OD* } \\
\text { (ICRS Grade 4) with } \\
\text { mean defect size } 8.1 \\
\text { sq.cm }\end{array}$ & $\begin{array}{l}\mathrm{MACl}+\text { cancelous bone } \\
\text { chips or monocortical } \\
\text { cancellos graft }\end{array}$ & autologous graft & $\begin{array}{c}\text { clinical improvement in IKDC, } \\
\text { Brittberg and ICRS score }\end{array}$ & Not available & No histology & No Arthroscopy \\
\hline $\begin{array}{l}\text { Steinhagen } \\
\text { et al,. } 2010\end{array}$ & $\begin{array}{l}22 \text { patients with OD* } \\
\text { (ICRS } 3 \text { and } 4 \text { )mean } \\
\text { age } 29.3 \text { years, mean } \\
\text { defect size } 6.57 \mathrm{sq} \mathrm{cm}\end{array}$ & $\begin{array}{c}\mathrm{MACl} \text { (Single } \\
\text { layer)+Bone plug }\end{array}$ & $\begin{array}{l}\text { proximal tibia with } \\
\text { diamond cutter } 2-3 \\
\text { depending }\end{array}$ & $\begin{array}{l}\text { Significant improvement in } \\
\text { Lysholm, IKDC up to } 12 \text { months } \\
\text { which was maintained till } 36 \\
\text { months. Defect }>6 \text { sq.cm } \\
\text { inferior outcome }\end{array}$ & No MRI scan & No histology & No Arthroscopy \\
\hline
\end{tabular}




\begin{tabular}{|c|c|c|c|c|c|c|c|}
\hline $\begin{array}{l}\text { Author \& } \\
\text { Year }\end{array}$ & $\begin{array}{c}\text { Patient } \\
\text { characteristics }\end{array}$ & Intervention & Bone graft & Clinical outcome & MRI feature & Histology & Arthroscopy \\
\hline $\begin{array}{l}\text { Och's et al,. } \\
2011\end{array}$ & $\begin{array}{l}26 \text { pts with OD* (ICRS } \\
3 \text { and } 4 \text { ), mean age } \\
29.2, \text { mean defect } \\
\text { size } 5.3 \text { sq. } \mathrm{cm} \text { and } \\
\text { depth } 8.7 \mathrm{~mm} \text {, }\end{array}$ & $\begin{array}{c}\mathrm{MACl} \text { (Single } \\
\text { layer)+Bone plug }\end{array}$ & $\begin{array}{l}\text { mono-cortical } \\
\text { cancellous } 8 \mathrm{~mm} \\
\text { diameter plug from } \\
\text { iliac crest or lateral } \\
\text { part of the fem } \\
\text { condyle(for } 1 \\
\text { plug)with a diamond } \\
\text { hollow drill with glue } \\
\text { in between the plugs }\end{array}$ & $\begin{array}{l}\text { Mean FU } 39.8 \text { months with } \\
\text { significant improvement in } \\
\text { Lysoholm-G an IKDC score at } 1 \\
\text { year which was maintained } \\
\text { subsequently, filling of the } \\
\text { defect and bone remodelling } \\
\text { significantly correlated with } \\
\text { Lysoholm-Gillquist and Tegner } \\
\text { scores }\end{array}$ & $\begin{array}{l}\text { Overall MOCART } \\
62.4+/-18.9 . \text { Lamina } \\
\text { remodelling grade } \\
\text { increased } \\
\text { significantly over } \\
\text { time during follow } \\
\text { up }\end{array}$ & No histology & No arthroscopy \\
\hline
\end{tabular}

Table 5 Summary of previous studies using ACl and bone graft to restore cartilage and subchondral defect in patients with an osteochondral

defect or patients with osteochondritis dissecans (OD) 
There are several reports in the literature of subchondral bone graft techniques in conjunction with cell therapy for cartilage repair. Impaction of loose cancellous bone was described by the proponents of the original 'sandwich' technique ${ }^{19}$ and kept unchanged in $\mathrm{BCMT}\left(\right.$ Table 4) ${ }^{1,27}$. Two studies described using a diamond core drill to harvest a monocortical graft 18,24 , although the cortical layer was removed in one study, effectively rendering those grafts to be cancellous bone cylinders ${ }^{24}$ (Table 4). A press-fit was attempted in these two studies by using more than one graft, with one study using fibrin glue between the grafts to ensure an adequate seal ${ }^{18}$ whilst the other used an under-sized core drill on the host bone to ensure a tight fit ${ }^{24}$. Both of these studies had uniform patient characteristics (ICRS 3 and $4 \mathrm{OD}$ ) and used a single layer of $\mathrm{MACl}$ with the cylindrical bone graft. Both studies reported a significant clinical improvement at a mean follow up of approximately 3 years ${ }^{18,24}$, though a poor clinical outcome was reported in defects larger than $6 \mathrm{~cm}^{2}$ with the use of cancellous bone cylinder grafts ${ }^{18,24}$. The Osplug technique uses a single mono-cortical graft which is precisely tailored to the dimension of the defect. In the present study, we demonstrate a similar functional outcome using this technique at a longer follow-up of 5 years. The outcome does not depend on defect area or depth or whether a first or second generation ACl was used. The present study also demonstrates Grade 4 (76100\%) lateral integration of the mono-cortical graft in 8 of 11 patients using the novel technique, which had significant positive correlation to the functional outcome at 1 year.

The only published study of patients with OD which were treated with bone graft and $\mathrm{ACl}$ reported MOCART scores of consecutive MRI scans from 26 patients treated with corticocancellous bone graft and single layer $\mathrm{MACl}^{18}$. This study found a mean value of $62 \pm 19 \mathrm{SD}$, comparable to our mean results of $61 \pm 22 \mathrm{SD}$ at 2.6 years ${ }^{18}$. A larger presence of a neo- 
lamina in our study was positively correlated with the duration between the surgery and the scan reinstating the previously hypothesized time dependent process of remodelling in the subchondral lamina ${ }^{18}$. There was no relationship of the grade of neo-lamina seen in MRI scans to the clinical outcome, overall MOCART score or lateral integration of the bone graft. This lack of correlation can be related to the small sample size in our work, causing type-2 errors. Nevertheless, the findings in earlier work ${ }^{18}$ and the present work consistently demonstrate the presence of the subchondral neo-lamina between repair cartilage and bone graft interface following concurrent use of cortico-cancellous cylinder grafts with $\mathrm{ACl}$.

This is the first report of histological assessment of the repair tissue following simultaneous bone graft and $\mathrm{ACl}$ using the ICRS $\|$ score ${ }^{12}$. The most striking and structurally relevant microscopic finding in these samples was the consistent integration between the repair cartilage and the underlying subchondral bone, implying interfacial bonding between the grafted bone and overlying repair cartilage. Interestingly, two patients had a biopsy taken at two time-points, both demonstrating an increase over time in scores for tissue morphology, cell morphology, subchondral bone and overall score. This suggests remodelling and maturation of the repair cartilage, as had previously been shown ${ }^{17}, 21$, in addition to a similar process occurring within the transplanted bone.

However, the present study has a small sample size of seventeen patients. To detect a large effect of the intervention (correlation coefficient of 0.5 ) we should ideally have 26 patients for the point-biserial correlation coefficient and 29 patients for Spearman's rank coefficient. This highlights the relative rarity of the condition from a single centre which is also evident from other published series ${ }^{1,16,27}$. 
In summary, the Osplug technique, combining a tailored mono-cortical autologous bone plug with $\mathrm{ACl}$, shows promising early and mid-term functional outcomes with first or second generation $\mathrm{ACl}$, irrespective of the size of the defect. A poor arthroscopic score and poor integration of the mono-cortical bone graft assessed with MRI is associated with poor clinical outcome and later failure of the intervention. Establishing good integration between the implanted cells and bone core appears critical to the long term success of the procedure. Once this is established, there appears to be improvement and maturation with time, both in the quality of the cartilage repair histologically and also the remodelling of the subchondral neo-lamina of the bone, particularly in those patients who go on to benefit clinically. 


\section{Figure captions}

Figure 1. Schematic diagram of the process of the OsPlug technique, which combines a bone plug with autologous chondrocyte implantation.

Figure 2. (A) Insertion of the OsPlug in the osteochondral defect of medial femoral condyle, followed by (B) second-generation autologous chondrocyte implantation on the restored subchondral bone.

Figure 3. Representative image of a tidemark (arrow) in one of the repair tissue biopsy specimens analyzed. Scale bar $=100 \mu \mathrm{m}$.

Figure 4. Sequential biopsy specimens at (A, B) 13 months and (C, D) 37 months after autologous chondrocyte implantation from patient 3 . Under polarized light (images $B$ and $D$ are polarized light images of the hematoxylin and eosin-stained sections in A and C, respectively), collagen fibers in the 13-month biopsy specimen can be seen running parallel in the bone to the cartilage-bone interface. By 37 months, these fibers within the bone can be seen to be more oblique and integrate between the cartilage and bone. Scale bars $=500 \mu \mathrm{m}$. b, bone; $c$, cartilage.

Figure 5. Sagittal image with proton-density turbo spin echo spectral fat saturation MRI sequence of the knee demonstrating cyst within the bone graft.

Figure 6. Sagittal image with proton-density turbo spin echo spectral fat saturation MRI sequence of the knee demonstrating homogeneous signal within the bone graft in comparison with the adjacent subchondral bone.

Figure 7. Representative images of a T2-weighted MRI sequence from the (A) coronal and (B) sagittal planes showing the lateral integration of the OsPlug with continuous trabecular pattern representing grade 4 (76\%-100\%) marginal integration of the subchondral bone graft and grade 4 (76\%-100\%) remodeling of lamina. 


\section{References}

1. Bartlett W, Gooding CR, Carrington RW, Skinner JA, Briggs TW, Bentley G. Autologous chondrocyte implantation at the knee using a bilayer collagen membrane with bone graft. A preliminary report. J Bone Joint Surg Br. 2005;87(3):330-332.

2. Brittberg M, Winalski CS. Evaluation of cartilage injuries and repair. J Bone Joint Surg Am. 2003;85-A Suppl 2:58-69.

3. Edmonds EW, Albright J, Bastrom T, Chambers HG. Outcomes of extra-articular, intraepiphyseal drilling for osteochondritis dissecans of the knee. J Pediatr Orthop. 2010;30(8):870-878

4. Edmonds EW, Polousky J. A review of knowledge in osteochondritis dissecans: 123 years of minimal evolution from Konig to the ROCK study group. Clin Orthop Relat Res. 2013;471(4):1118-1126.

5. Erickson BJ, Chalmers PN, Yanke AB, Cole BJ. Surgical management of osteochondritis dissecans of the knee. Curr Rev Musculoskelet Med. 2013;6(2):102-114.

6. Gudas R, Gudaite A, Pocius A, et al. Ten-year follow-up of a prospective, randomized clinical study of mosaic osteochondral autologous transplantation versus microfracture for the treatment of osteochondral defects in the knee joint of athletes. Am J Sports Med. 2012;40(11):2499-2508.

7. Gudas R, Stankevicius E, Monastyreckiene E, Pranys D, Kalesinskas RJ. Osteochondral autologous transplantation versus microfracture for the treatment of articular cartilage defects in the knee joint in athletes. Knee Surg Sports Traumatol Arthrosc. 2006;14(9):834842.

8. Harrison PE, Ashton, K., Johnson,W.E.B., Turner, S.L., Richardson, J.B., Ashton, B.A. . The in vitro growth of human chondrocytes. Cell And Tissue Banking 2000;1:255-260 
9. Kocher MS, Micheli LJ, Yaniv M, Zurakowski D, Ames A, Adrignolo AA. Functional and radiographic outcome of juvenile osteochondritis dissecans of the knee treated with transarticular arthroscopic drilling. Am J Sports Med. 2001;29(5):562-566.

10. Kouzelis A, Plessas S, Papadopoulos AX, Gliatis I, Lambiris E. Herbert screw fixation and reverse guided drillings, for treatment of types III and IV osteochondritis dissecans. Knee Surg Sports Traumatol Arthrosc. 2006;14(1):70-75.

11. Laprell H, Petersen W. Autologous osteochondral transplantation using the diamond bonecutting system (DBCS): 6-12 years' follow-up of 35 patients with osteochondral defects at the knee joint. Arch Orthop Trauma Surg. 2001;121(5):248-253.

12. Mainil-Varlet P, Van Damme B, Nesic D, Knutsen G, Kandel R, Roberts S. A new histology scoring system for the assessment of the quality of human cartilage repair: ICRS II. Am J Sports Med. 2010;38(5):880-890.

13. Makino A, Muscolo DL, Puigdevall M, Costa-Paz M, Ayerza M. Arthroscopic fixation of osteochondritis dissecans of the knee: clinical, magnetic resonance imaging, and arthroscopic follow-up. Am J Sports Med. 2005;33(10):1499-1504.

14. Marlovits S, Singer P, Zeller P, Mandl I, Haller J, Trattnig S. Magnetic resonance observation of cartilage repair tissue (MOCART) for the evaluation of autologous chondrocyte transplantation: determination of interobserver variability and correlation to clinical outcome after 2 years. Eur J Radiol. 2006;57(1):16-23.

15. Marlovits S, Striessnig G, Resinger CT, et al. Definition of pertinent parameters for the evaluation of articular cartilage repair tissue with high-resolution magnetic resonance imaging. Eur J Radiol. 2004;52(3):310-319.

16. Maus U, Schneider U, Gravius S, et al. [Clinical results after three years use of matrixassociated ACT for the treatment of osteochondral defects of the knee]. Z Orthop Unfall. 2008;146(1):31-37. 
17. McCarthy HS, Roberts S. A histological comparison of the repair tissue formed when using either Chondrogide((R)) or periosteum during autologous chondrocyte implantation. Osteoarthritis Cartilage. 2013;21(12):2048-2057.

18. Ochs BG, Muller-Horvat C, Albrecht D, et al. Remodeling of articular cartilage and subchondral bone after bone grafting and matrix-associated autologous chondrocyte implantation for osteochondritis dissecans of the knee. Am J Sports Med. 2011;39(4):764773.

19. Peterson L, Minas T, Brittberg M, Lindahl A. Treatment of osteochondritis dissecans of the knee with autologous chondrocyte transplantation: results at two to ten years. J Bone Joint Surg Am. 2003;85-A Suppl 2:17-24.

20. Roberts S, Menage J. Microscopic methods for the analysis of engineered tissues. Methods Mol Biol. 2004;238:171-196.

21. Roberts S, Menage J, Sandell LJ, Evans EH, Richardson JB. Immunohistochemical study of collagen types I and II and procollagen IIA in human cartilage repair tissue following autologous chondrocyte implantation. Knee. 2009;16(5):398-404.

22. Smith GD, Taylor J, Almqvist KF, et al. Arthroscopic assessment of cartilage repair: a validation study of 2 scoring systems. Arthroscopy. 2005;21(12):1462-1467.

23. Smith HJ, Richardson JB, Tennant A. Modification and validation of the Lysholm Knee Scale to assess articular cartilage damage. Osteoarthritis Cartilage. 2009;17(1):53-58.

24. Steinhagen J, Bruns J, Deuretzbacher G, Ruether W, Fuerst M, Niggemeyer O. Treatment of osteochondritis dissecans of the femoral condyle with autologous bone grafts and matrixsupported autologous chondrocytes. Int Orthop. 2010;34(6):819-825.

25. Suri S, Walsh DA. Osteochondral alterations in osteoarthritis. Bone. 2012;51(2):204-211.

26. Talkhani IS, JB R. Knee diagram for the documentation of arthroscopic findings of the knee cadaveric study. The Knee 1999;6:95-101. 
27. Vijayan S, Bartlett W, Bentley G, et al. Autologous chondrocyte implantation for osteochondral lesions in the knee using a bilayer collagen membrane and bone graft: a twoto eight-year follow-up study. J Bone Joint Surg Br. 2012;94(4):488-492.

28. Welsch GH, Mamisch TC, Zak L, et al. Evaluation of cartilage repair tissue after matrixassociated autologous chondrocyte transplantation using a hyaluronic-based or a collagenbased scaffold with morphological MOCART scoring and biochemical T2 mapping: preliminary results. Am J Sports Med. 2010;38(5):934-942.

29. Wright RW, McLean M, Matava MJ, Shively RA. Osteochondritis dissecans of the knee: longterm results of excision of the fragment. Clin Orthop Relat Res. 2004(424):239-243. 


\section{Overview of OsPlug - Autologous Chondrocyte Implantation}

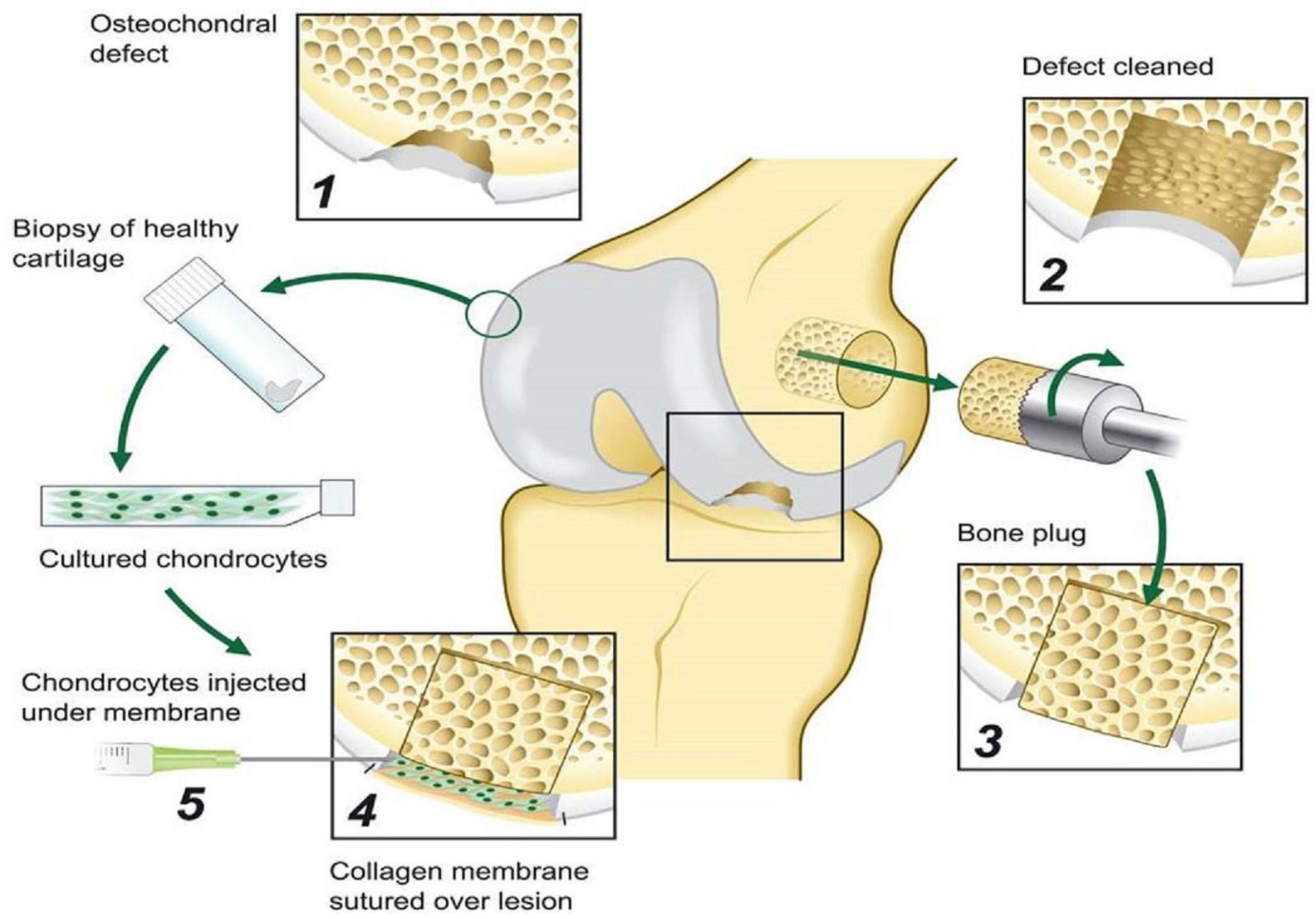

Figure 1 


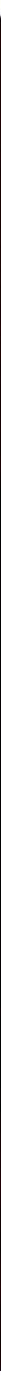

Figure 2 


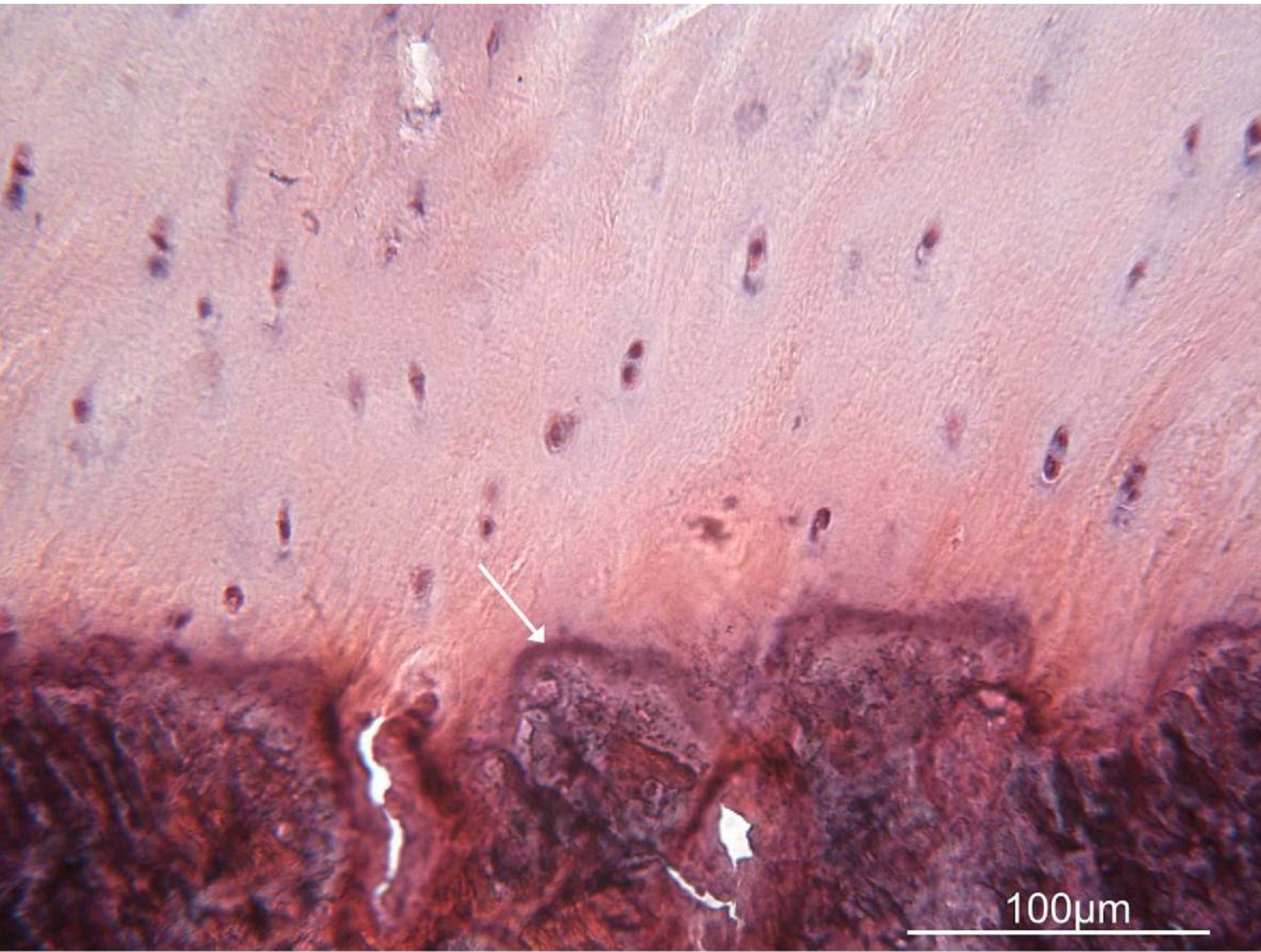

Figure 3 


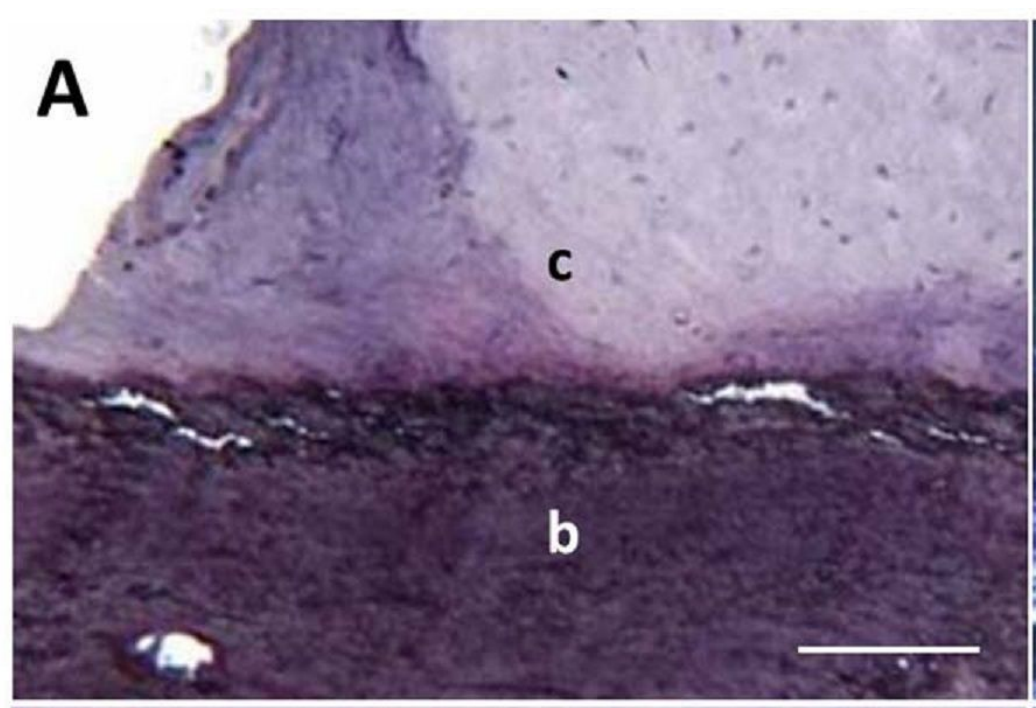

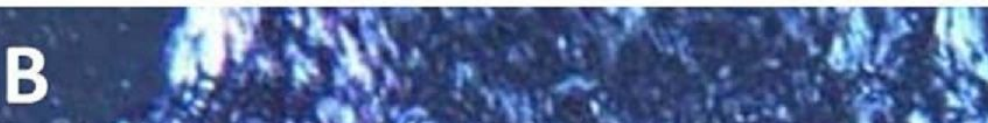

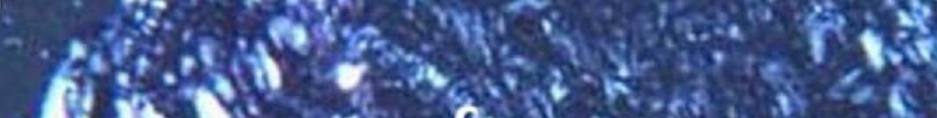

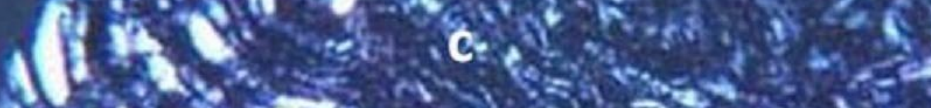

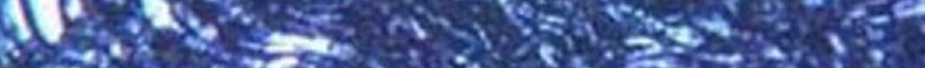

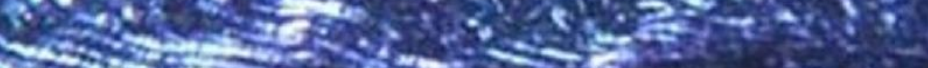
expos
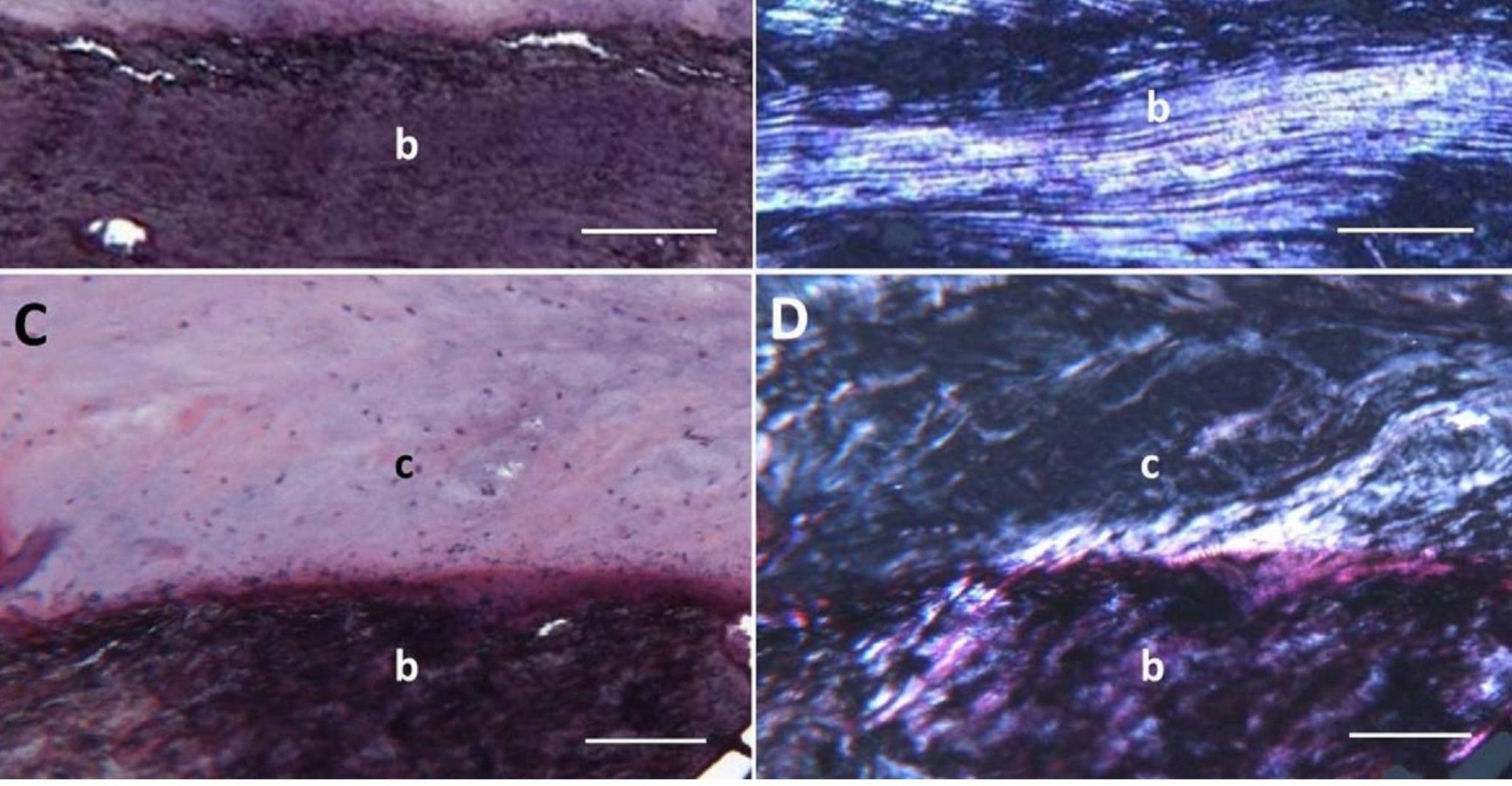

Figure 4 


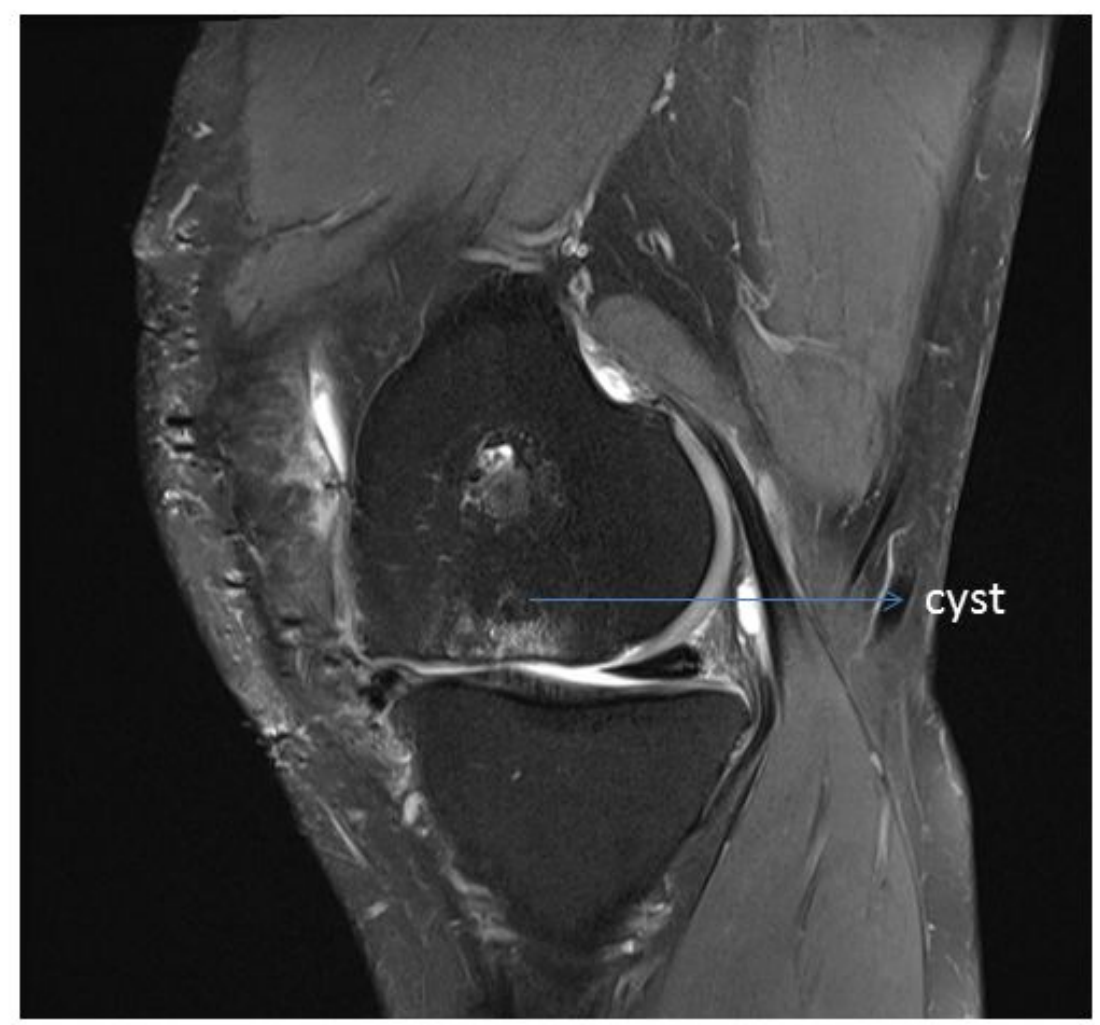

Figure 5 


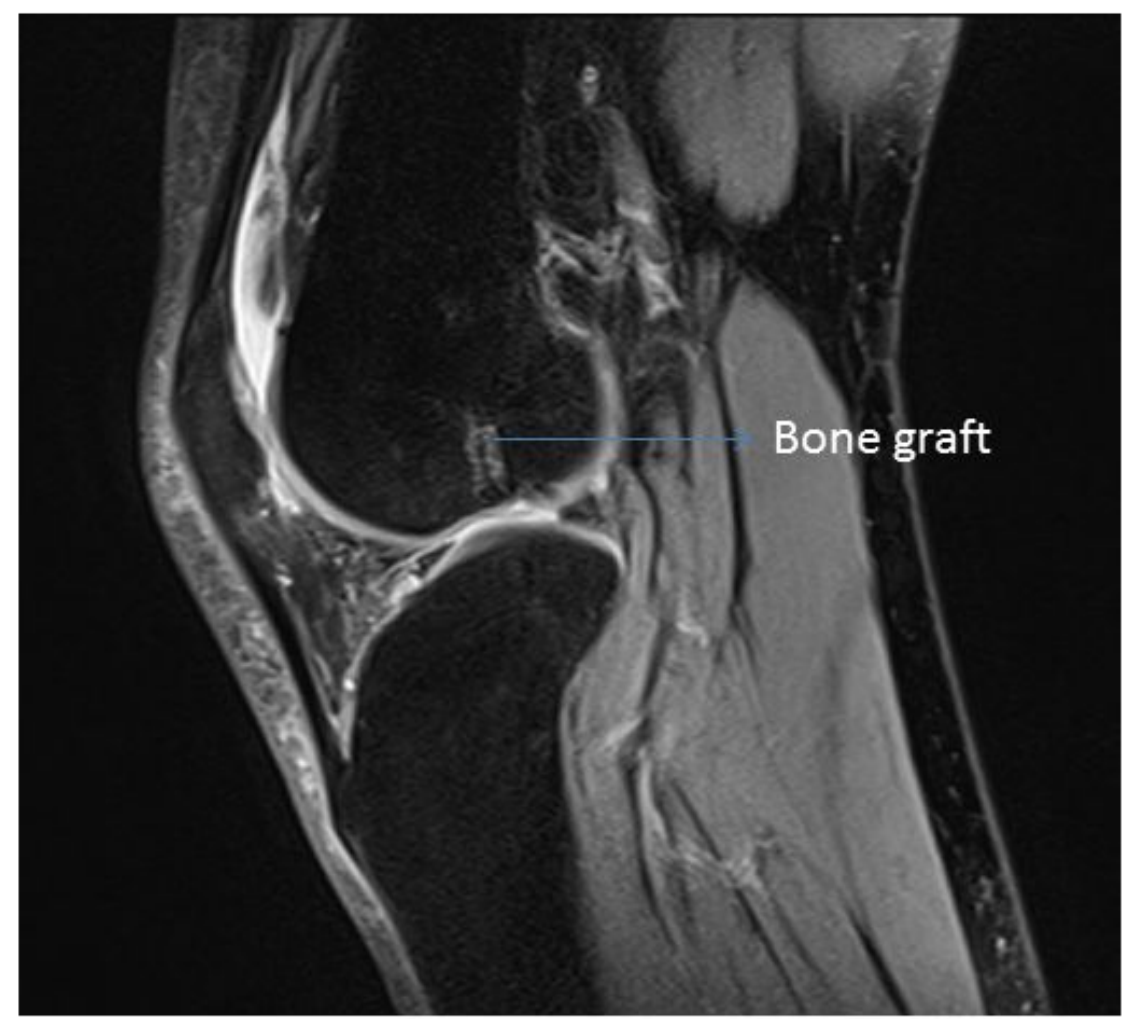

Figure 6 


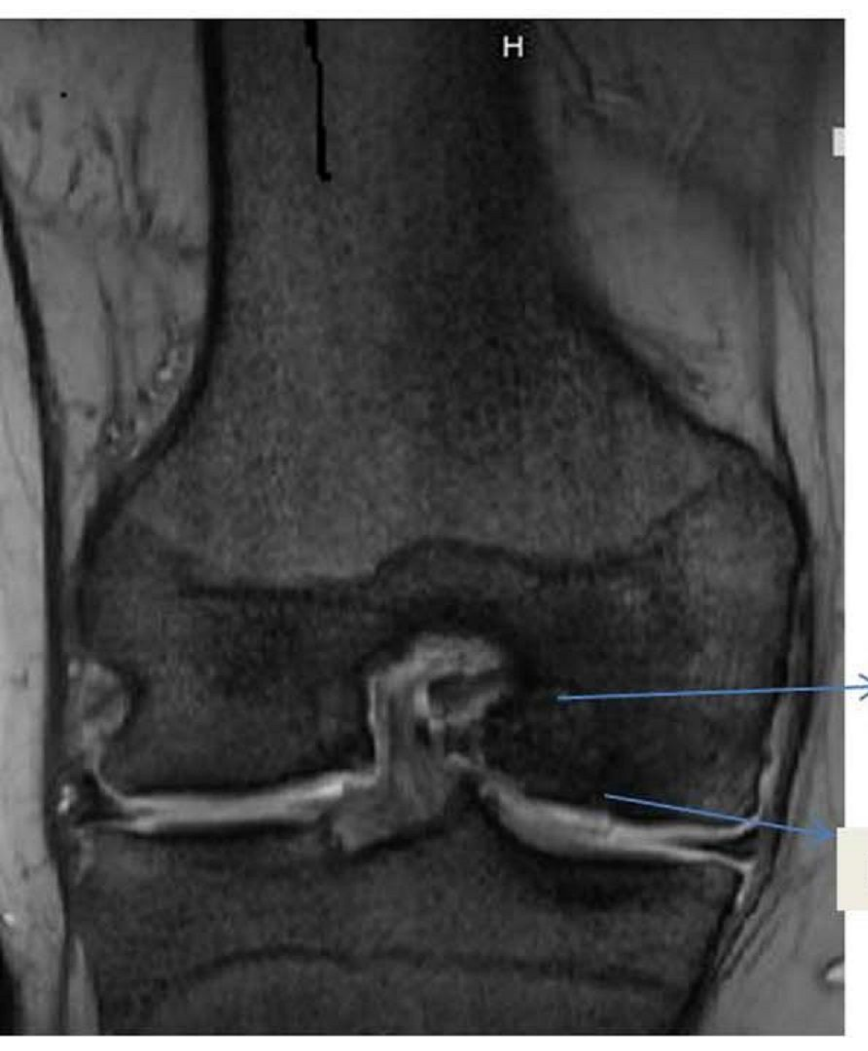

a. Coronal image

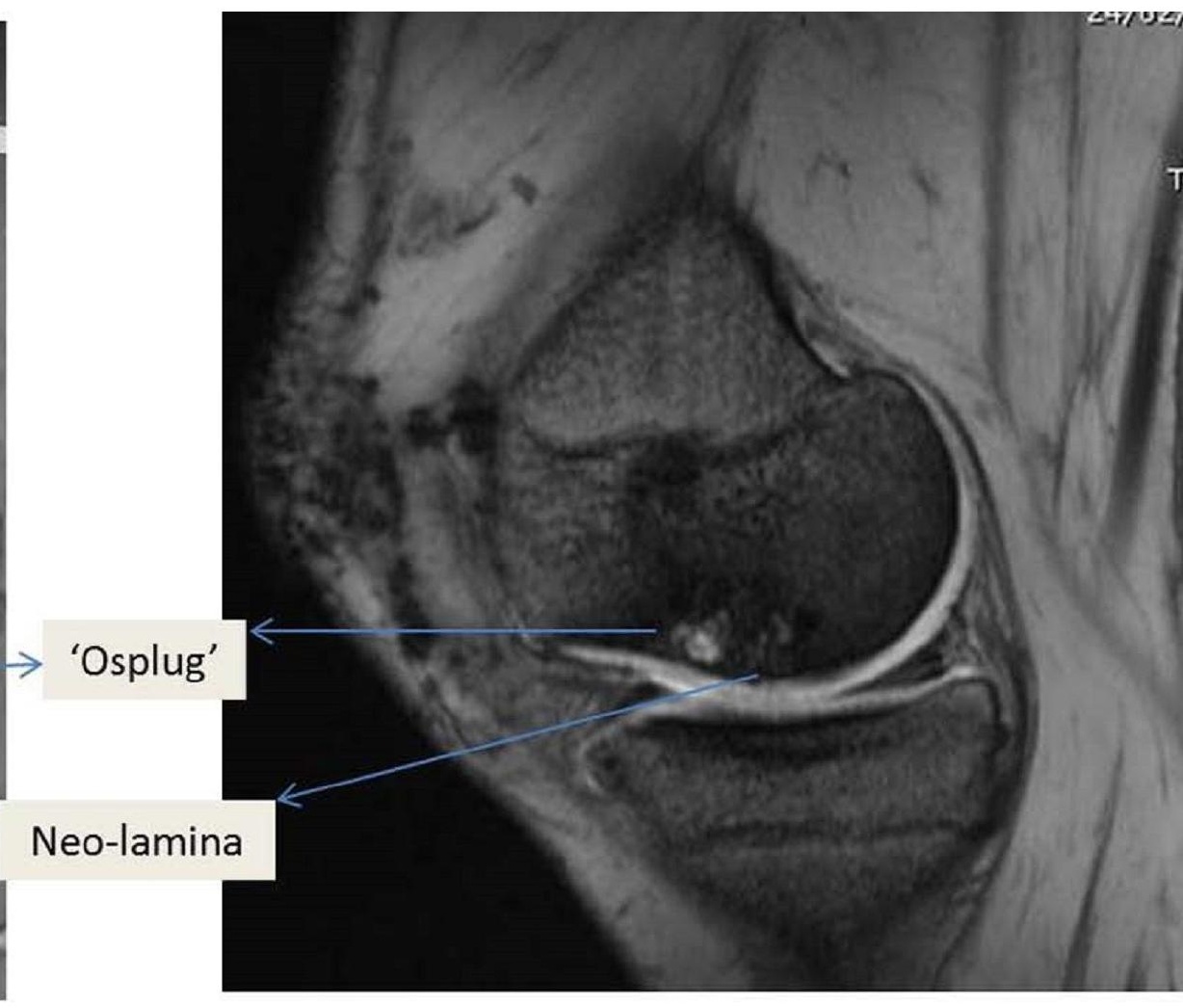

b. Sagittal image

Figure 7 